\title{
CODE-MIXING IN INDONESIAN SELEBGRAM'S CAPTION IN INSTAGRAM
}

\author{
Iis Risliyanti ${ }^{1}$, Setiana Sri Wahyuni Sitepu ${ }^{2}$, Muhammad Ahsan Tampubolon ${ }^{3}$ \\ Universitas Pamulang \\ iis.risliyanti@gmail.com
}

\begin{abstract}
The use of code-mixing in any social media platform rises significantly. As one of currently popular social media, Instagram is mostly-found platform to mixing languages in users' caption posts. Observing 10 captions written by an instagrambased influencer known with selebgram, this study aims at (1) finding out codemixing practices from the captions; and (2) classifying them into types of codemixing based on Musyken's theory. The captions were written by a celebrity, a trendsetter for Indonesian teenagers who use English as their target language. This study finds that (1) there are 10 code-mixing uses found in the 10 captions which are classified into (2) alternation type for 8 times, and congruent lexicalization type for 2 times.
\end{abstract}

Keyword: language, communication, code-mixing, social media, instagram.

\section{INTRODUCTION}

This universe has thousands of languages that survive this long. Different languages are usually arising from cultural differences called cultural communities. Everyone is born to master their first language. When someone uses another language to communicate, this is a practice of communication in a second language in order to make communication with people who do not use the same language possible. The one who communicate in their second language is called bilingual person, and therefore has ability to mix and switch the languages properly. The statement is reinforced by Wardhaugh (2006) that the phenomenon of people having more than one code is called bilingualism or multilingualism. Then this is also said by Spolsky (1998) states that someone is bilingual when they have several functional abilities in the second language.

Further, Wardhaugh (2006) mentions that when someone talks to an interlocutor using two languages together to extend that these languages change from one to the other within a single utterance, code-mixing occurs. From several phenomena that occur between mixed codes, Hoffman in Pardede and Kisno (2012) explains some reasons why these people (bilingual and multlingual) switch or mix their language are (1) they talk about a particular topic; (2) they quote from somebody else; (3) they are emphatic about things they find, (4) to produce interjection, or including sentence cohesive devices), (5) clarifying by using repetition, (6) intentionally trying to clarify content of the speech for interlocutor and (6) expressing group identity and entity. 
In this digital era, communication does not only occur in face-to-face moment but also in many platforms, such as social media. Social media is a bridge between people to stay in touch even though the distance separates and no need to meet each other. Social media makes the enthusiasts of people easier to share their moment. People use social media as a place for them to express the feelings from what they feel and experience. It can be a post that tells the daily activity along with a photo upload and caption. The social media that is being discussed is Instagram. This platform begins to be popularized on October 6, 2010 which begins its initial release on the App Store and can be accessed also on Google Play. Code-mixing can be found in one of Instagram users who often labeled it as a Selebgram or abbreviation for Celebrity of Instagram. The selebgram uploads daily photos and important moments written in a caption containing code-mixing. This research focuses on this topic because this code often occurs when the selebgram uses code-mixing to express its writing and makes it easier to communicate with all Instagram users throughout the world. The selebgram is also one of the biggest influencers who reached $859 \mathrm{~K}$ followers, including Indonesian citizens. She is being followed because of the development of her language in using code-mixing on Instagram captions.

Related studies are taken into account to enrich the analysis of our study. The first study is by Sutrismi (2014) entitled the use of Indonesian English code mixing in social media networking (Facebook) By Indonesian Youngsters. This study was aimed to portray (1) code mixing's types and (2) the reasons why people use code mixing in social media platform (Facebook) especially Indonesian youngsters. This study shows that there are six types of linguistic forms of code-mixing and three reasons of using code-mixing. The similarity of this study is to identify the types of code-mixing used in form of social media and the difference is how each study collects the data from the social media; this study uses Instagram and Sutrismi's study uses Facebook to college the data of using codemixing and gives reasons of using codemixing.

Another study was conducted by Novianti (2013) entitled the use of code switching in Twitter (A case study in English Education Department). This study aims to (1) identify code switching types in the tweets, (2) explore the reasons why the respondents choose to switch their language in Twitter, (2) to analyze by some steps, the code switching occurences from the tweets, (3) making classification of the code switching occurences in the form of tables, (4) quantifying the level of code switching's frequency and its percentage, and (5) analyzing and discussing the obtained data. The study finds that there are three types of code switching, seven language combinations and six reasons of the use of code switching in Twitter. The similarities of this study are to identify and to classify the type of code-mixing of the data in form of table from social media. The differences of this study are the type of data; this study is identifying the type of code-mixing and Novianti's study is identifying the type of code-switching and also she gives seven language combinations and six reasons of the use of code switching.

And the third study is by Yuliana, Luziana, and Sarwendah (2015) CodeMixing And Code-Switching of Indonesian Celebrities: A Comparative Study. The purpose of this study is to obtain some information to identify the types of code mixing and code switching frequently used by Indonesian celebrities. The similarity of this study is to identify the type of codemixing in celebrities as they use to 
communicate and the differences are the type of code-switching that she uses as the purpose of the study and the objective of the study.

This study examined the using of code-mixing which happens to some people who have a great chance to become influencers. The procedures used in this study include; (1) identifying the types of code-mixing from the caption and (2) classifying the caption based on the types of code-mixing. The final results are to discovery several types in code-mixing and presented in the form of table. This study also aims to describe several types of codemixing so the readers know more about how to use code-mixing.

\section{METHOD}

In this study, the method used to collect the data is the descriptive qualitative approach. The data collection requires from one of the social media objects to observe problems in language development that occur in real life. This statement is also supported by Robson (2002) cited in Cohen et. al. (2007), case study looks at a phenomenon in its real-life context. This research is conducted to examine the types of code-mixing that exist from several selections of captions used by one of Indonesian selebgram which become the main focus of this research, also she is the biggest influencer that can be followed because of the language development in terms of code-mixing itself.

There are several ways to analyze the data obtained. First, researchers took 10 captions from May to June 2019 on the Instagram platform. Second, several captions are collected by identifying the code-mixing in terms of writing the caption. Third, the caption is being classified by the types of code-mixing into 3 types according to the theory of Muysken (2000). And finally, the caption is written in the form of a table and the type of code-mixing that occurs in writing the caption.

\section{DISCUSSIONS}

To strengthen this study, Muysken's theory is used to determine the type of codemixing contained in the caption. Muysken (2000) also revealed that code-mixing is generally divided into three main types. They are (1) insertion (word or phrase level), alternation (clause level) and congruent lexicalization (dialectic level) and the frequently-used occurrence of codemixing variants in society is insertion one. By insertion, the writer thinks is the process of code-mixing which is conceived as something to borrowing: the insertion of an alien lexical or phrasal category into a given structure. Alternation means the altering process between structures from languages. It occurs between clauses that alternation is used when speaker mixes his or her language with a phrase. The last is congruent lexicalization of material from different lexical inventories into a shared grammatical structure.

This theory helps the writers to analyze all the code mixing occurences found in the instagram account of the celebrity. The analysis is in form of table that covers the captions as well as its class which is based on Muysken's theory. Further, this study is sharpened with the type that dominates. The complete classification can be found in Table 1 . 


\section{Table 1. Type of Code Mixing of Captions Written by a Selebgram}

\begin{tabular}{l|l|c}
\hline NO. & \multicolumn{1}{|c}{ CAPTION } & \multicolumn{1}{c}{ CODE- } \\
MIXING
\end{tabular}

\begin{tabular}{|c|c|c|}
\hline & $\begin{array}{l}\text { man. Because nobody is. } \\
\text { Dan once seseorang made } \\
\text { mistake, langsung } \\
\text { berbondong-bondong di- } \\
\text { cancel orang-orang. People } \\
\text { are not perfect. People } \\
\text { change. They grow. } \\
\text { Terkadang manusia suka } \\
\text { enggak masuk akal. }\end{array}$ & \\
\hline 3 & 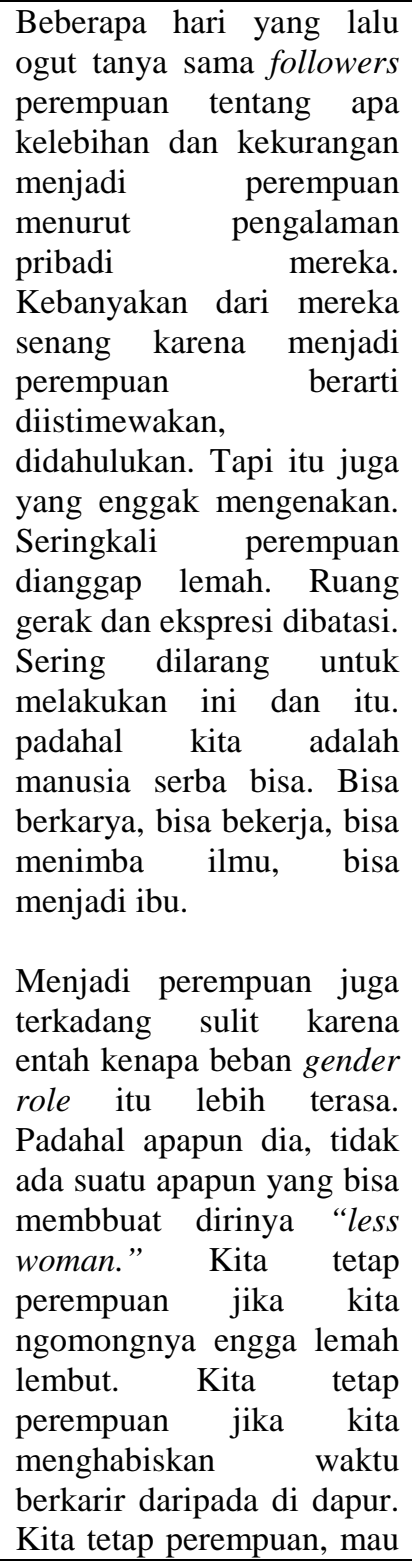 & Insertion \\
\hline
\end{tabular}




\begin{tabular}{|c|c|c|}
\hline & $\begin{array}{l}\text { apapun sifat kita, kegiatan } \\
\text { kita, profesi kita. } \\
\text { Apapun itu, kita tetap } \\
\text { perempuan hebat. }\end{array}$ & \\
\hline 4 & 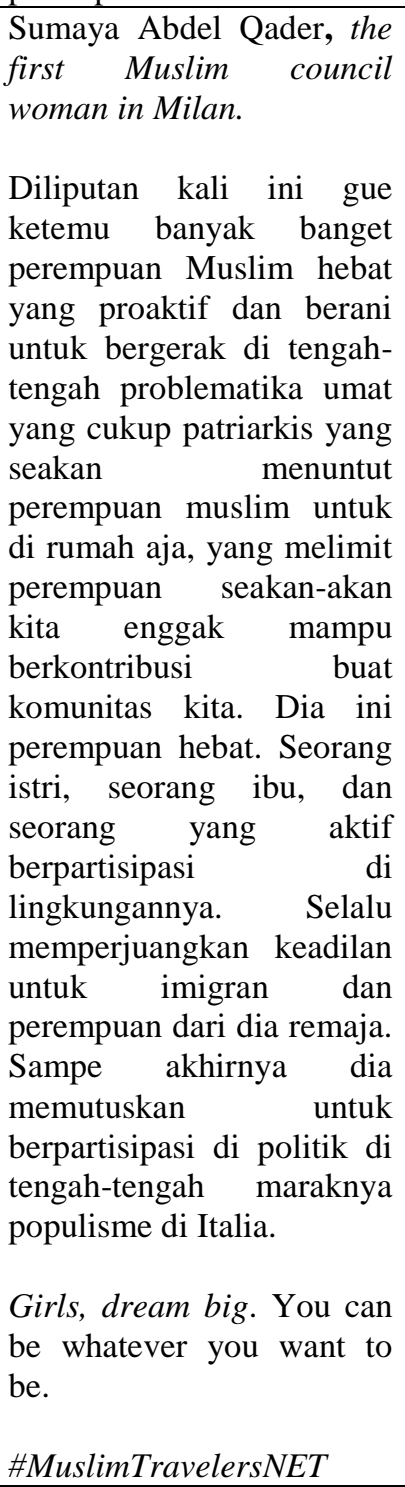 & $\begin{array}{c}\text { Insertion } \\
\text { and } \\
\text { Alternation. }\end{array}$ \\
\hline 5 & $\begin{array}{l}\text { Weekend ini pada ada } \\
\text { tontonan nggak? Vlog di } \\
\text { Swiss dan Prancis udah ada } \\
\text { di Youtube ya! My } 9 \text { day } \\
\text { trip packed in one video } \\
\text { Anyway, kalian ada dream } \\
\text { country yang pengen } \\
\text { kalian samperin nggak sih? } \\
\text { Share in the comment } \\
\text { section down below which } \\
\text { country and why! }\end{array}$ & $\begin{array}{l}\text { Insertion } \\
\text { and } \\
\text { Alternation }\end{array}$ \\
\hline 6 & $\begin{array}{l}\text { Enjoying the view of Bern. } \\
\text { Jangan lupa pake }\end{array}$ & Insertion \\
\hline
\end{tabular}

\begin{tabular}{|c|c|c|}
\hline & $\begin{array}{l}\text { sunscreen } \\
\text { @ mdglowingskin biar kulit } \\
\text { tetep terjaga }\end{array}$ & $\begin{array}{c}\text { and } \\
\text { Alternation }\end{array}$ \\
\hline 7 & $\begin{array}{l}\text { The only picture in the city. } \\
\text { Inilah mengapa disarankan } \\
\text { untuk stay di suatu kota } \\
\text { jangan cuma } 2 \text { hari. } \\
\text { Apalagi kalau flight-nya } \\
\text { sekitar } 12 \text { jam (plus drama } \\
\text { koper) }\end{array}$ & $\begin{array}{l}\text { Insertion } \\
\quad \text { and } \\
\text { Alternation }\end{array}$ \\
\hline 8 & $\begin{array}{l}\text { I am finally in Japan! We } \\
\text { managed to stroll around } \\
\text { Dotonburi area after } \\
\text { having dinner. We will be } \\
\text { there only for two days but } \\
\text { we will come back for sure } \\
\text { Captured } \\
\text { \#GooglePixel3a Night } \\
\text { Sight feature } \\
\text { Btw apakah media sosial } \\
\text { masih di-block, guys? } \\
\text { p.s.: I'm not planning to } \\
\text { make any PagiPagi } \\
\text { regarding the riot } \\
\text { yesterday. Why u ask? } \\
\text { Karena kalau urusan } \\
\text { politik Indonesia dan } \\
\text { Pemilu, I'm trying my best } \\
\text { not to add another noise. } \\
\text { Karena udah berisik even } \\
\text { without me talking about it. } \\
\text { Too many sides dan cerita- } \\
\text { cerita segala macem. Kaya } \\
\text { yang gue mention kemaren } \\
\text { di komen, setiap orang } \\
\text { punya versinya sendiri. But } \\
\text { one thing I believe, politik } \\
\text { engga bisa diliat terlalu one } \\
\text { dimensional. Gue titip } \\
\text { pesen aja, aside any of this } \\
\text { drama, kita semua sama- } \\
\text { sama orang Indonesia. } \\
\text { \#TeamPixel } \\
\text { \#TeamBuburDiAduk }\end{array}$ & $\begin{array}{l}\text { Insertion } \\
\text { and } \\
\text { Alternation, }\end{array}$ \\
\hline 9 & $\begin{array}{l}\text { Vlog pindahan soon yes. } \\
\text { Sebelum itu tonton dulu } \\
\text { vlog terakhir ogut di Italia. } \\
\text { Selasa depan ada episode } \\
\text { baru PagiPagi. \#sekilasinfo }\end{array}$ & $\begin{array}{c}\text { Insertion } \\
\text { and } \\
\text { Congruent } \\
\text { Lexicalization } \\
\end{array}$ \\
\hline
\end{tabular}




\begin{tabular}{|c|c|c|}
\hline 10 & $\begin{array}{l}\text { Last week } \\
\text { @soundsofindonesia we } \\
\text { talked about the } \\
\text { importance of digital } \\
\text { literacy and I shared my } \\
\text { experience online. Thanks } \\
\text { to you who came AND } \\
\text { actually listened to our talk } \\
\text { show. Gue pribadi merasa } \\
\text { sangat penting untuk terus } \\
\text { raising awareness dan } \\
\text { tetap berdiskusi tentang } \\
\text { isu-isu seputaran internet } \\
\text { dan behavior orang } \\
\text { terhadapnya. Karena tidak } \\
\text { bisa dipungkiri, walaupun } \\
\text { internet memberikan } \\
\text { banyak manfaat ia juga } \\
\text { memberikan masalah baru }\end{array}$ & $\begin{array}{c}\text { Insertion, } \\
\text { Alternation, } \\
\text { and } \\
\text { Congruent } \\
\text { Lexicalization }\end{array}$ \\
\hline
\end{tabular}

\section{CONCLUSION}

This study concludes that the major type of code-mixing used in the selected caption from Indonesian selebgram's Instagram is insertion based on the samples from this study. The type of insertion is found 10 times in each caption. And then the second most is the type of alternation is found 8 times, and the last one is the type of congruent lexicalization, which is found 2 times in writing the caption on Indonesian Selebgram's Instagram. Based on the caption, the Indonesian selegram uses the level of words, phrase, and clause to combine between the native language and target language, which is English language, to write down the caption as the expression of what being described in the Instagram uploaded-picture. This shows the background of Indonesian Selebgram is bilingual or uses two languages to communicate.

Therefore, the selebgram prefers to use code mixing to help develop their skills in English language as well as the lack of vocabulary in her native language so she uses the target language to communicate in two languages, especially in English language.

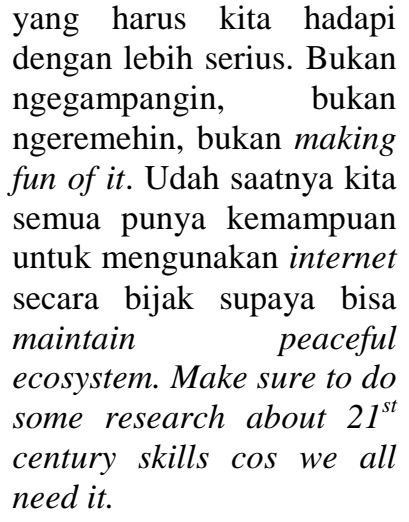

\section{REFERENCES}

Louis Cohen; Lawrence Manion; Keith Morrison. (2007). Research Methods in Education (6th Edition ed.). London and New York: Taylor \& Francis eLibrary.

Muysken, P. (2000). Bilingual Speech: A Typology of Code-Mixing. London: Cambridge University Press.

Novianti, Widya. (2013). The Use of Code Switching in Twitter (A Case Study in English Education Department). Retrieved on June $23^{\text {rd }}, 2019$ from http://ejournal.upi.edu/index.php/psg/ar ticle/view/532

Pardede, Hilman and Kisno. (2012). Introduction to Sociolinguistics: From General to Local Perspectives. Jakarta Batam: Halaman Moeka - LLc Publishing.

Spolsky, B. (1998). Sociolinguistics. Oxford: Oxford University Press.

Sutrismi, Sutrismi (2014) The Use Of Indonesian English Code Mixing In Social Media Networking (Facebook) By Indonesian Youngsters. Skripsi thesis, Universitas Muhammadiyah Surakarta. 
Wardhaugh, Ronald. (2006). An Introduction to Sociolinguistics (5th Edition ed.). Oxford: Blackwell Publishing.

Yuliana, Nana, Rosa Luziana, Amelia, Sarwendah, Pininto. (2015). CodeMixing and Code-Switching of Indonesian Celebrities: A Comparative Study. Jakarta: Lingua Cultura. 